\title{
TRADISI BHEN-GHIBEN PADA PERKAWINAN ADAT MADURA (STUDI KASUS DI KABUPATEN SUMENEP-MADURA)
}

\author{
Jamiliya Susantin ${ }^{1}$, Syamsul Rijal ${ }^{2}$ \\ 1,2Universitas Islam Madura Pamekasan Madura \\ *Corresponding Author email : jamiliyasusantin@gmail.com, rijal.rij2211@gmail.com
}

\begin{tabular}{|c|c|}
\hline \multirow{3}{*}{$\begin{array}{l}\text { Diterima : } \\
\text { Bulan Januari } \\
2021\end{array}$} & Abstrak \\
\hline & $\begin{array}{l}\text { Tradisi Ben-Ghiben adalah tradisi membawa barang oleh pengantin pria kerumah } \\
\text { penganten wanita berupa alat-alat rumah tangga, yakni lemari, kursi, tempat tidur, }\end{array}$ \\
\hline & $\begin{array}{l}\text { dan semua jenis perlengkapan dapur. Tujuan dari penelitian ini adalah untuk } \\
\text { mengetahui dan menganalisis tentang tradisi Ben-Ghiben perkwinan adat Madura. } \\
\text { Adapun metodeloginya adalah kualitatif dengan tahapan penelitian 1. observasi, }\end{array}$ \\
\hline Diterbitkan : & 2. wawancara dan 3. dokumentasi. Untuk analisis data dengan menggunakan \\
\hline Bulan Februari & analisis deskriptif-fenomelogis. Hasil dari penelitian adalah tradisi perkawinan di \\
\hline 2021 & $\begin{array}{l}\text { Madura berbeda dengan Tradisi perkawinan di jawa, kalau di Madura menganut } \\
\text { mayoritas menganut tradisi matrilineal, dimana suami-istri setelah melangsungkan }\end{array}$ \\
\hline Keyword: & perkawinan dituntut untuk tinggal dirumah istri. Dan calon suami membawa Bhen- \\
\hline Tradisi, & Gibhen (barang bawaan berupa lemari, kursi, tempat tidur dan perabotan rumah \\
\hline Ben-Ghiben, & tangga lainnya). Dan istri menyediakan rumah untuk ditempati. \\
\hline $\begin{array}{l}\text { Perkawinan, } \\
\text { Madura }\end{array}$ & \\
\hline
\end{tabular}

\section{PENDAHULUAN}

Tradisi merupakan norma yang mengatur hubungan manusia dengan manusia yang lain baik individual maupun kelompok, manusia bertindak terhadap lingkungannya, dan perilaku manusai terhadap alam yang lainnya. Kemudian ia berkembang menjadi suatu system, memiliki pola dan norma yang sekaligus juga mengatur penggunaan saksi dan ancaman terhadap pelanggaran dan peyimpangan.

Dalam literatur Islam adat atau kebiasaan disebut العرف yang berarti adat atau kebiasaan. Menurut Abdul Wahab Khalaf, 'Urf adalah sesuatu yang telah diketahui orang banyakdan dikerjakan oleh mereka, yang berupa perkataan, perbuatan atau sesuatu yang di tinggalkan. Hal ini dinamakan pula dengan al-'adah. Dalam bahasa ahli syara' tidak ada perbedaan antara al-'urf dan al-'adah. ${ }^{1}$

Perkawinan adalah ikatan lahir dan batin antara pria dan wanita yang sah secara hokum agama dan Negara. Tujuan dari perkawinan adalah membentuk keluarga kecil yang terdiri suami dan istri.

Tradisi perkawinan di Madura merupakan tradisi yang kental dengan system kekerabatan matrilokal dimana pasangan suami istri tinggal dirumah istri. Ada beberapa persyaratan yang harus dilakukan oleh calon suami untuk melangsungkan perkawinan yakni dengan membawa perabotan rumah tangga ke rumah istri yang disebut Bhen-Gibhen. Dan calon istri menyiapkan rumah untuk ditempati.

Menurut salah satu tokoh masyarakat Bapak Lukman bahwa tradisi Bhen-Gibhen adalah tradisi yang sudah dilakukan oleh orang-orang terdahulu dan orang tua kita sendiri terlibat dalam tradisi tersebut. Tradisi perkawinan akan dianggap sempurna kalau calon suami membawa BhenGibhen ke rumah istri. Adapun Bhen-Gibhen tersebut berupa kasur, lemari dan kursi dan perabotan rumah tangga lainnya. Dan apabila tidak mengikuti tradisi ini ada sanksi sosial sehingga menjadi bahan gunjingan oleh masyarakat.

Tradisi pernikahan budaya Madura merupakan tradisi pernikahan yang sangat menarik untuk diteliti, karena berbeda dengan tradisi-tradisi pulau seberangnya salah satunya yaitu pulau Jawa. Tidak hanya beberapa serangkaian prosesi upacaranya saja yang unik akan tetapi dalam hal Perayaan dan juga penyuguhan makanannya yang tergolong mewah, tanpa memandang status sosial dari keluarga tersebut.

Fenomena menarik untuk dikaji tentang tradisi benghiben pada perkawinan adat Madura, dimana ada sebongkah harapan dan tujuan adanya tradisi tersebut. Yang dimaksud ben-ghiben adalah barang yang dibawa oleh pengantin pria kerumah penganten wanita berupa alat-alat rumah tangga,

\footnotetext{
${ }^{1}$ Wahhab Khallaf, Kaidah-Kaidah Hukum Islam. (Bandung: Risalah, 1999), hlm. 131
} 
yakni lemari, kursi, tempat tidur, dan semua jenis perlengkapan dapur. Fenomena ini sudah mentradisi dan tidak dapat dihindari

\section{Metode Penelitian}

Adapun metode pendekatan penelitian ini adalah kualitatif. Menurut Tadjoer Ridjal penelitian yang menggunakan penelitian kualitatif bertujuan menggali atau membangun suatu proposisi atau menjelaskan dibalik realita. ${ }^{2}$ Dan jenis penelitian Fenomenologis yakni penelitian fakta sosial tentang sebuah tradisi yang mengakar di masyarakat dan sangat sulit untuk dirubah yakni tradisi ben-ghiben pada perkawinan adat Madura.

Penelitian ini menggunakan pendekatan kualitatif (qualitative approach) dengan metode fenomenologis. Pendekatan kualitatif merupakan prosedur penelitian yang menghasilkan data deskriptif berupa kata-kata (ucapan), tulisan, dan prilaku dari orang-orang yang diamati.

\section{Pembahasan dan Hasil Penelitian}

\section{Tradisi Bhen-Gibhen pada Perkawinan Adat Madura}

Tradisi Bhen-Gibhen adalah tradisi turun temurun dari para leluhur pada perkawinan adat Madura, yakni tradisi membawa barang bawaan dari rumah suami ke rumah istri berupa tempat tidur, lemari beserta isinya, kursi dan perlengkapan lainnya. Tradisi perkawinan ini dilakukan saat walimatul 'urs (pesta perkawinan). Karena pada hakikatnya perkawian adat di kabupaten Sumenep menganut siste kekerabatn matrilokal, karena suami ikut kerumah istri.

Menurut system perkawinan adat di Indonesia Tradisi Bhen-Gibhen pada perkawinan adat di kabupaten sumenep ini masuk pada Tradisi Perkawinan semendo pada hakikatnya bersifat matrilokal dan exogami. Matrilokal berarti bahwa isteri tidak berkewajiban untuk bertempat tinggal di kediaman suami. Dalam perkawinan ini biasa dijumpai dalam keadaan darurat, di mana perempuan sulit mendapatkan jodoh atau karena laki- laki tidak mampu untuk memberikan jujur. ${ }^{3}$

Tradisi ketika calon suami mempersiapkan BhenGibhen, maka calon Istri mempersiapkan rumah kosong, rumah kosong tersebut di isi oleh calon suami yang disebut Bhen-Gibhen.

2 Burhan Bungin, ed, Metodelogi Penelitian Kualitatif, Aktualisasi Metodelogia kearah Ragam Varian Kontemporer, (Jakarta: RajaGrafindo Persada, 2007), hlm. 124
Membawa istri kerumah suami Bhen-Gibhen pun harus lengkap dirumah istri, baik beruapa uang tunai atau barang. Juga suami diharuskan mempersiapkan rumah dan Bhen-Gibhen dirumah yang ingin ditempati.

Tradisi yang unik adalah ketika ada pasangan menikah yang bercerai, maka Bhen-Gibhen tersebut diambil kembali oleh mantan suami dengan syarat apabila mereka ridak mempunyai anak, namun apabila mempunyai anak, maka Bhen-Gibhen tersebut di wariskan kepada anaknya yang masih dalam asuhan ibunya.

Adapun tujuan perkawinan bagi masyarakat adat yang bersifat kekerabatan adalah untuk mempertahankan dan meneruskan keturunan menurut garis kebapakan atau keibuan atau keibubapakan, untuk kebahagiaan rumah tangga keluarga/kerabat, untuk memperoleh nilai-nilai adat budaya dan kedamaian, dan untuk mempertahankan kewarasan. Oleh karena sistem keturunan dan kekerabatan antara suku bangsa Indonesia yang satu dan lain berbeda-beda, maka tujuan perkawinan adat bagi masyarakat juga berbeda antara suku bangsa yang satu dan daerah yang lain, begitu juga dengan akibat hukum dan upacara perkawinannya. ${ }^{4}$

Dalam masyarakat Patrineal, perkawinan bertujuan untuk mempertahankan garis keturunan bapak, sehingga anak laki-laki (tertua) harus melaksanakan bentuk perkawinan ambil isteri (dengan pembayaran uang jujur), dimana setelah terjadi perkawinan, istri ikut (masuk) dalam kekerabatan suami dan melepaskan kedudukan adatnya dalam susunan kekerabatan bapaknya. Sebaliknya dalam masyarakat matrineal, perkawinan bertujuan untuk mempertahankan garis keturunan ibu, sehingga anak perempuan (tertua) harus melaksanakan bentuk perkawinan ambil suami (semando) dimana setelah terjadinya perkawinan suami ikut (masuk) dalam kekerabatan isteri dan melepaskan kedudukan adatnya dalam susunan kekerabatan orangtuanya. ${ }^{5}$

Melihat fakta sosial tentang tradisi Bhen-Gibhen pada perkawinan adat Madura merupakan sebuah fenomenologi yang tak bias dihindari lagi. Ada beberapa unsure yang menjadi sebuah kewajiban dari pihak penganten pria untuk membawa perlengkapan rumah tangga yakni untuk menjaga keharmonisan, mengapa keharmonisan harus

\footnotetext{
${ }^{3}$ Ibid., Hlm. 24

${ }^{4}$ Hilman Hadikusuma, 1990, Hukum Perkawinan Indonesia Menurut Perundangan, Hukum Adat, Agama, Bandung, Hlm. 23

${ }^{5}$ Ibid.,
} 
dengan membawa perlengkapan rumah tangga tersebut? Karena melihat fakta sosial yang sudah sering terjadi, ketika mantan suami tidak membawa bhe-gibhen, maka akan lebih mudah untuk meninggalkan atau menceraikan istri karena sudah tidak mempunyai beban yang banyak atau tidak mempunyai modal banyak ketika menjalani pernikahan. Kenapa penulis sampaikan modal disini? Karena ada beberapa alas an. Alasan yang pertama, ketika pengantin pria tidak memilki modal, fakta sosial mendapatkan bahwa pernikahan hanya akan menjadi fenomena tidak penting, sehingga niat untuk meninggalkan istri akan lebih mudah. Kedua, sebagai tujuan untuk kepentingan hubungan suamiistri beserta keturunannya.

Melihat fenomena yang sudah mentradisi tersebut urgen untuk dikaji dalam rangka mengenalkan tradisi adat perkawinan Madura. Kemudian dari bebeeapa factor yang mempengaruhi fenomena yang sudah mentradisis tersebut apabila dianalisa dari kajian sosiologi hokum adalah sebagi berikut:

\section{Analisis Tradisi Bhen-Gibhen Pada Perkawinan Adat Madura Perspektif Sosiologi Hukum}

System Perkawinan Adat Menurut hukum adat, sistem perkawinan ada 3 macam yaitu:

1. Sistem Endogami

Dalam sistem ini orang hanya diperbolehkan kawin dengan seseorang dari suku keluarganya sendiri. Sistem perkawinan ini jarang terjadi di Indonesia. Menurut Van Vollenhoven hanya ada satu daerah saja secara praktis mengenal sistem endogami ini, yaitu daerah Toraja. Tapi sekarang di daerah ini pun sistem akan lenyap dengan sendirinya kalau hubungan darah itu dengan daerah lainnya akan menjadi lebih mudah, erat dan meluas. Sebab sistem tersebut di daerah ini hanya terdapat secara praktis saja, lagi pula endogami sebetulnya tidak sesuai dengan sifat susunan kekeluargaan yang ada di daerah itu, yaitu Parental. ${ }^{6}$

\section{Sistem Exogami}

Dalam sistem ini, orang diharuskan menikah dengan suku lain. Menikah dengan suku sendiri merupakan larangan. Namun demikian, seiring berjalannya waktu, dan berputarnya zaman lambat laun mengalami proses perlunakan sedemikian rupa, sehingga larangan perkawinan itu diperlakukan hanya pada lingkungan kekeluargaan yang sangat kecil saja. Sistem ini dapat di jumpai daerah Gayo,

6 Soerjono Soekanto, 1992, Intisari Hukum Keluarga, Bandung, Citra Aditya Bakti, Hlm.132 7 Ibid.

${ }^{8}$ Ibid, Hlm.132-133
Alas, Tapanuli, Minangkabau, Sumatera Selatan, Buru dan Seram. ${ }^{7}$

3. Sistem Eleutherogami

Sistem Eleutherogami berbeda dengan kedua sistem diatas, yang memiliki larangan-larangan dan keharusan- keharusan. Eleutherogami tidak mengenal larangan- larangan dan keharusankeharusan tersebut. Larangan- larangan yang terdapat dalam sistem ini adalah larangan yang terdapat dalam sistem ini adalah larangan yang berhubungan dengan ikatan kekeluargaan yang menyangkut nasab (keturunan) seperti kawin dengan ibu, nenek, anak kandung, cucu, juga dengan saudara kandung, saudara bapak atau ibu. Atau larangan kawin dengan musyahrah (per-iparan) seperti kawin dengan ibu tiri, mertua, anak tiri. ${ }^{8}$ Dalam sistem ini dapat di jumpai hampir di seluruh masyarakat Indonesia.

Di Indonesia dapat di jumpai tiga bentuk perkawinan adat, antara lain:

Bentuk perkawinan jujur (bridge-gif marriage)

Kawin jujur merupakan bentuk perkawinan di mana pihak laki-laki memberikan jujur kepada pihak perempuan. Benda yang dapat dijadikan sebagai jujur biasanya benda- benda yang memiliki magis. Pemberian jujur diwajibkan adalah untuk mengembalikan keseimbangan magis yang semula menjadi goyah, oleh karena terjadinya kekosongan pada keluarga perempuan yang telah pergi karena menikah tersebut. Perkawinan jujur di jumpai pada masyarakat Patrineal. Ciri- ciri perkawinan jujur adalah patrilokal, artinya isteri bertempat tinggal di kediaman suami atau keluarga suami. ${ }^{9}$ Di samping itu perkawinan jenis ini bersifat exogami yaitu larangan untuk menikah dengan warga yang se-clan atau se-marga.

\section{Bentuk perkawinan semendo (suitor service marriage)}

Perkawinan semendo pada hakikatnya bersifat matrilokal dan exogami. Matrilokal berarti bahwa isteri tidak berkewajiban untuk bertempat tinggal di kediaman suami. Dalam perkawinan ini biasa dijumpai dalam keadaan darurat, di mana perempuan sulit mendapatkan jodoh atau karena laki- laki tidak mampu untuk memberikan jujur. ${ }^{10}$

Bentuk perkawinan bebas (exchange marriage) Dalam bentuk kawin bebas tidak menentukan secara tegas dimana suami atau isteri akan tinggal, hal ini

\section{${ }^{9}$ Soerojo Wignjodipoero, 1989, Pengantar Dan \\ Asas Hukum Adat, Bandung Hlm. 128}

${ }^{10}$ Ibid., Hlm. 24 
tergantung pada keinginan masing- masing pihak. Bentuk kawin bebas ini bersifat endogami, artinya suatu anjuran untuk kawin dengan warga kelompok kerabat sendiri. ${ }^{11}$

Adapun tujuan perkawinan bagi masyarakat adat yang bersifat kekerabatan adalah untuk mempertahankan dan meneruskan keturunan menurut garis kebapakan atau keibuan atau keibubapakan, untuk kebahagiaan rumah tangga keluarga/kerabat, untuk memperoleh nilai-nilai adat budaya dan kedamaian, dan untuk mempertahankan kewarasan. Oleh karena sistem keturunan dan kekerabatan antara suku bangsa Indonesia yang satu dan lain berbeda-beda, maka tujuan perkawinan adat bagi masyarakat juga berbeda antara suku bangsa yang satu dan daerah yang lain, begitu juga dengan akibat hukum dan upacara perkawinannya. ${ }^{12}$

Dalam masyarakat Patrineal, perkawinan bertujuan untuk mempertahankan garis keturunan bapak, sehingga anak laki-laki (tertua) harus melaksanakan bentuk perkawinan ambil isteri (dengan pembayaran uang jujur), dimana setelah terjadi perkawinan, istri ikut (masuk) dalam kekerabatan suami dan melepaskan kedudukan adatnya dalam susunan kekerabatan bapaknya. Sebaliknya dalam masyarakat matrineal, perkawinan bertujuan untuk mempertahankan garis keturunan ibu, sehingga anak perempuan (tertua) harus melaksanakan bentuk perkawinan ambil suami (semando) dimana setelah terjadinya perkawinan suami ikut (masuk) dalam kekerabatan isteri dan melepaskan kedudukan adatnya dalam susunan kekerabatan orangtuanya. ${ }^{13}$

Melihat fakta sosial tentang tradisi Bhen-Gibhen pada perkawinan adat Madura merupakan sebuah fenomenologi yang tak bias dihindari lagi. Ada beberapa unsure yang menjadi sebuah kewajiban dari pihak penganten pria untuk membawa perlengkapan rumah tangga yakni untuk menjaga keharmonisan, mengapa keharmonisan harus dengan membawa perlengkapan rumah tangga tersebut? Karena melihat fakta sosial yang sudah sering terjadi, ketika mantan suami tidak membawa bhe-gibhen, maka akan lebih mudah untuk meninggalkan atau menceraikan istri karena sudah tidak mempunyai beban yang banyak atau tidak mempunyai modal banyak ketika menjalani pernikahan. Kenapa penulis sampaikan modal disini? Karena ada beberapa alas an. Alas an yang

11 Ibid., Hlm. 25

12 Hilman Hadikusuma, 1990, Hukum Perkawinan Indonesia Menurut Perundangan, Hukum Adat, Agama, Bandung, Hlm. 23 pertama, ketika pengantin pria tidak memilki modal, fakta sosial mendapatkan bahwa pernikahan hanya akan menjadi fenomena tidak penting, sehingga niat untuk meninggalkan istri akan lebih mudah. Kedua, sebagai tujuan untuk kepentingan hubungan suamiistri beserta keturunannya.

Melihat fenomena yang sudah mentradisi tersebut urgen untuk dikaji dalam rangka mengenalkan tradisi adat perkawinan Madura. Kemudian dari bebeeapa factor yang mempengaruhi fenomena yang sudah mentradisis tersebut apabila dianalisa dari kajian sosiologi hokum adalah sebagi berikut:

\section{Teori Fenomenologi Alfred Schutz}

Teori fenomenogi menurut Alfred Schutz adalah dipusatkan terhadap satu aspek dunia sosial yang disebut kehidupan dunia atau dunia kehidupan sehari-hari. Inilah yang disebut dunia intersubyektif. Dalam dunia intersubyektif ini orang menciptakan realitas sosial dan dipaksa oleh kehidupan sosial yang telah ada dan oleh struktur kultural ciptaan leluhur mereka. Didalam dunia kehidupan itu banyak aspek kolektifnya, tetapi juga ada aspek pribadinya. Schutz membedakan dunia kehidupan antara hubungan tatap muka yang akrab dan hubungan interpersonal dan renggang. Sementara hubungan tatap muka yang intim sangat penting dalam kehidupan dunia, adalah jauh lebih mudah bagi sosiolog untuk meneliti hubungan interpersonal secara ilmiah. Meski Schuutz beralih perhatiannya dari kesadaran ke dunia kehidupan intersubyektif, namun ia masih mengemukakan hasil pemikirannya tentang kesadaran, terutama pemikirannya tentang makna dan motif tindakan individual.

Dari teori ini schutz berpendapat bahwa tindakan manusia menjadi suatu hubungan sosial bila manusia memberikan arti atau makna tertentu terhadap tindakannya itu, dan manusia lain memahami pula tindakannya itu sebagai sesuatu yang penuh arti.

Maka dari berbagai konsep pemikiran schutz, perkawinan adat Madura yang mayoritas memakai tradisi perkawinan matrilokal, diama si suami bertempat tinggal dirumah istri, dengan memenuhi syarat harus yakni Bhen-Gibhen, tradisi BhenGibhen pada perkawinan adat Madura merupakan aturan yang harus dijalani masyarakat, yang apabila 
tidak dilaksanakan ada sanksinya, baik sanksi moril maupun materiil.

Hokum adat memanglah bukan aturan tertulis namun apabila dilanggar maka ada akibat hokum. Hal ini apabila dikembalikan kepada pasal II aturan Peralihan Undang-Undang Dasar 1945 yang menyatakan bahwa "segala badan negara dan peraturan yang ada masih langsung berlaku selama belum diadakan yang baru menurut Undang-Undang Dasar ini, maka termasuk di dalamnya adalah hukum-hukum adat yang masih berlaku.

Senada dengan pendapat Van Apeldom memberikan 2 syarat untuk terbentuknya hukum kebiasaan/adat istiadat yaitu; 1) yang bersifat materiil pemakaian yang tetap; 2) Yang bersifat psykhologis (bukan psikologis perorangan melainkan psikologis golongan), keyakinan akan kewajiban hukum. ${ }^{14}$

Lebih lanjut Apeldom mengatakan bahwa keyakinan akan kewajiban hukum tentu tak perlu sejak semula melekat pada kebiasaan dan biasanyapun tidak demikian. Keyakinan itu sebaliknya acapkali timbul dari kejadian sebenamya belaka.

Jika sesuatu tetap berlaku, lama kelamaan timbul pikiran pada manusia bahwa memang haruss demikian, dan kemudian acapkali timbul pikiran bahwa menurut hukum memang demikian. Ini adalah kekuasaan kebiasaan yang dialami oleh tiaptiap orang dalam hidupnya sendiri, tetapi yang terlihat juga dalam hubungan manusia satu sama lain dan demikian juga dalam hukum. Demikian acapkali timbulah susila dari kebiasaan dan dari susila timbul hukum.

Ungkapan Apeldorn tersebut memberikan gambaran bahwa adat dapat mempunyai akibat/sanksi hukum setelah terjadi kristalisasi dari tingkah laku susila dalam kehidupan mereka.

\section{Teori fakta sosial Emile Durkheim}

Fakta sosial menurut Emile Durkheim terdiri atas dua macam:

Bentuk material, yakni sesuatu barang yang dapat disimak, ditangkap dan diobservasi. Fakta sosial yang berbentuk material ini adalah bagian dari

${ }^{14}$ Apeldom, Van.L.J. Pengantar limit Hukum, (Jakarta: Pradya Paramita, 1978)., hal. 123

${ }^{15}$ George Ritzer, Sosiologi Ilmu Pengetahuan Berparadigma Ganda, (Jakarta: Raja Grafindo, 2011) ., hal. 14 dunia nyata (external word). Misal: arsitektur dan norma Hukum.

Bentuk nomaterial, yakni sesuatu yang dianggap nyata (external). Fakta sosial jenis ini merupakan fenomena yang bersifat inter subjektif yang hanya dapat muncul dari dalam kesadaran manusia. Misal, egoisme, altruisme, dan opini. ${ }^{15}$

Arsitektur dan norma hokum meruapak barang sesuatu material karena keduanya bias disimak dan diobservasi. Semisal norma hukum sangan mudah untuk dipahami dan nyata ada dalam mempengaruhi kehidupan masyarakat, baik individu maupun kolektif.

Sedangkan opini sebagai fakta sosial yang lain hanay dapat dinyatakan sebagai barang sesuatu, tidak dapat diraba, yang dalam kesadaran manusia. Dari asumsi tersebut Durkheim menyampaikan bahwa fakta sosial nonmaterial ini melawan psikologi, dimana menurutnya psikologi telah mengancam sosiologi setelah filsafat.

Durkheim menyampaikan bahwa individu dibentuk oleh masyarakat, dasar pemikiran inilah yang dimaksud fakta sosial. Yang mana pada dasarnya individu memiliki keinginan sendiri, namun karena lingkungan sosialnya maka sangat mempengaruhi kehiduapan individu. Proses pemaksaan ini tidak sepenuhnya terjadi secara ekstrim dan ketat, namun melalui sosialisasi yang memungkinkan proses pemaksaan terjadi tanpa disadari.

Dari pemaparan fakta sosial Emile Durkheim dikaitkan dengan tradisi Bhen-Gibhen perkawinan adat Madura merupakan tradisi yang terjadi secara alamiyah, sehingga apabila ada sebagian dari masyarakat yang tidak mampu secara financial atas tradisi tersebut akan menjadi bahan perbincangan dahsyat, hal inilah yang menjadi sanksi moril. Maka atas fenomena ini, masyarakat mempunyai kesadaran kolektif yang membuahkan nilai-nilai dan menjadikan nilai-nilain tersebut sebagai sesuatu yang ideal perindividual. Tradisi Bhen-Gibhen ini terbentuk bukan karena adanya kesenangan ${ }^{16}$ atau kontrak sosial, namun melainkan adanya factor lain yang lebih penting dari itu yakni collective conciousness atau kesadaran kolektif.

\footnotetext{
${ }^{16}$ Kesenangan disini dimaksudkan kesenangan akan barang bawaan pengantin pria ke rumah pengantin wanita, karena pengantin wanita tidak akan bersusah payah mengeluarkan biaya untk mengisi perabotan dalam rumahnya.
} 
Ada dua bentuk kesadaran kolektif menurut Wirawan yakni

Exterior adalah kesadaran yang berada diliuar individu yang sudah mengalami proses internalisasi ke dalam individu dalam wujud aturan-aturan moral, agama, nilai, (baik, buruk, luhur mulia) dan sejenisnya.

Constrain adalah kesadaran kolektif yang memilki daya paksa terhadap individu, dan akan mendapat sanksi tertentu jika hal itu dilanggar. Ada dua tipe constrain menurut Durkheim represif dan restitutif. ${ }^{17}$

\section{Kesimpulan}

Tradisi merupakan aspek kebudayaan daerah dan sekaligus produk dari sejarah lokal yang dapat menambah khasanah budaya daerah bahkan nasional.

Konsep pemikiran schutz terkait tradisi BhenGibhen perkawinan adat Madura yang mayoritas memakai tradisi perkawinan matrilokal, dimana si suami bertempat tinggal dirumah istri, dengan memenuhi syarat harus yakni Bhen-Gibhen, tradisi Bhen-Gibhen pada perkawinan adat Madura merupakan aturan yang harus dijalani masyarakat, yang apabila tidak dilaksanakan ada sanksinya, baik sanksi moril maupun materiil. Fakta sosial Emile Durkheim dikaitkan dengan tradisi Bhen-Gibhen perkawinan adat Madura merupakan tradisi yang terjadi secara alamiyah, sehingga apabila ada sebagian dari masyarakat yang tidak mampu secara financial atas tradisi tersebut akan menjadi bahan perbincangan dahsyat, hal inilah yang menjadi sanksi moril. Maka atas fenomena ini, masyarakat mempunyai kesadaran kolektif yang membuahkan nilai-nilai dan menjadikan nilai-nilain tersebut sebagai sesuatu yang ideal perindividual. Tradisi Bhen-Gibhen ini terbentuk bukan karena adanya kesenangan atau kontrak sosial, namun melainkan adanya factor lain yang lebih penting dari itu yakni collective conciousness atau kesadaran kolektif.

\section{Daftar Pustaka}

Hadikusuma, Hilman, Hukum Perkawinan Indonesia Menurut Perundangan, Hukum Adat, Agama, Bandung, 1990.

Khallaf, Wahhab, Kaidah-Kaidah Hokum Islam, Bandung: Risalah, 1999.

Ritzer, George dan Goodman, Douglas J, Teori Sosiologi Modern (Jakarta: Predana Media, 2008.

Ritzer, George, Sosiologi Ilmu Pengetahuan Berparadigma Ganda, Jakarta: Raja Grafindo, 2011.

Schutz, Alfred dalam John Wild dkk, The Phenomenology of the Sosial World. Illinois Northon University Press, 1967.

Soekanto, Soerjono, Intisari Hukum Keluarga, Bandung: Citra Aditya Bakti, 1992.

Syafe'I, Rahmat, Ilmu Ushul Fiqh, Bandung; Pustaka Setia, 2000.

Undang-Undang Republik Indonesia Nomor 1 Tahun 1974 Tentang Perkawinan dan Kompilasi Hukum Islam, Bandung: Citra Umbara, 2007.

Van.L.J. Apeldom, Pengantar limit Hukum, Jakarta: Pradya Paramita, 1978.

Wignjodipoero, Soerojo, Pengantar Dan Asas Hukum Adat, Bandung: 1989.

Wirawan,I.B., Teori-Teori Dalam Tiga Paradigma, Jakarta: Kencana PrenadaMedia Group, 2013

${ }^{17}$ I.B. Wirawan, Teori-Teori Dalam Tiga Paradigma, (Jakarta: Kencana PrenadaMedia Group, 2013), hal. 17. 